\title{
Mapping Inter and Transdisciplinary Relationships in Architecture: A First Approach to a Dictionary under Construction
}

\author{
By Clara Germana Gonçalves* \\ Maria João Soares ${ }^{\dagger}$
}

This paper serves as part of the groundwork for the creation of a transdisciplinary dictionary of architecture that will be the result of inter and transdisciplinary research. The body of dictionary entries will be determined through the mapping of interrelating disciplines and concepts that emerge during said research. The aim is to create a dictionary whose entries derive from the scope of architecture as a discipline, some that may be not well defined in architecture but have full meanings in other disciplines. Or, even, define a hybrid disciplinary scope. As a first approach, the main entries - architecture and music, architecture and mathematics, architecture, music and mathematics, architecture and cosmology, architecture and dance, and architecture and cinema - incorporate secondary entries - harmony, matter and sound, full/void, organism and notation - for on the one hand these secondary entries present themselves as independent subjects (thought resulting from the main) and on the other they present themselves as paradigmatic representative concepts of a given conceptual context. It would also be of interest to see which concepts are the basis of each discipline and also those which, while not forming the basis, are essential to a discipline's operationality. The discussion is focused in the context of history, the varying disciplinary interpretations, the differing implications those disciplinary interpretations have in the context of architecture, and the differing conceptual interpretations. The entries also make reference to important authors and studies in each specific case. Within the context of the dictionary idea, the paper also aims to be a showcase and motive for debate on architecture in general, and architecture in contemporaneity in particular.

\section{Introduction}

Architecture today is still an area of knowledge that is not closely associated with specialization; it is naturally interconnected with other fields. This is manifest not only in its more practical aspects, but also, and more interestingly from the point of view of this paper, in its more theoretical aspects. Architecture is a privileged discipline in terms of interdisciplinary dialogue, as it is a field where specialization, in contrast to other fields, carries less weight. It is also traditionally a field that is rooted in multidisciplinary knowledge. This is made evident from the

${ }^{*}$ Researcher, CITAD, Lusíada University / Associate Professor, ISMAT, Portimão, Portugal.

${ }^{\dagger}$ Associate Professor, CITAD, Lusíada University, Portugal. 
ideas advanced by Vitruvius ${ }^{1}$ to the contemporary study plans of the various modern schools. This reality should be seen as one full of creative potential and not as a shortcoming in the current context of over-specialization.

Throughout the history of architecture many questions have emerged on its relationship with other fields of knowledge. Those questions have reflected both the intellectual reality of a specific period in general and the reality as it applied to architecture in particular.

Some of those questions are: Which disciplines interact with architecture? Why these particular disciplines? In what way(s) do they interact with architecture? What type of relationship governs their interaction? Is it based on language? Based on concepts? When do such relationships take place? What periods are most paradigmatic for each type of relationship? In what conceptual contexts? Which authors have put these relationships into practice and which have theorized on them? What are the results of these inter and/or transdisciplinary relationships? What is the outcome of the answers to these questions; or, rather, what is the outcome of the search for answers to these questions?

Interdisciplinary relationships can be fundamentally important instruments for a discipline's understanding of itself, as well as autonomous areas of knowledge.

Notwithstanding our desire for this project to be based on contributions from diverse authors, due to the limited scope of this paper we have opted for the selection of specific entries, leaving others for future development.

At this point the relation between architecture and the so called fine arts will not take place for these relationships have been carried out traditionally and are more common.

\section{An Inter and Transdisciplinary Dictionary of Architecture}

The idea is to create a dictionary based on contributions by diverse authors. It may also include entries on which there are varying viewpoints.

The aim is to contribute to thought on the very essence of architecture; to reflect on architecture. A look at architecture beyond architecture or as another architecture.

Some of the relationships are based on theory, others on the practice. In conceiving and building this dictionary we are committed, on the one hand, to the current zeitgeist as a foundation, but also believe in analogous situations that may not necessarily be concurrent. As according to Antoine Picon and Alessandra Ponte: "[T]he various aspects of a culture depend upon very different systems of temporality. The rhythms of the history of art and architecture are not similar to those of mathematics and physics: the interruptions and disjunctions in their development do not usually occur at the same moment, often chronological

1. Right at the beginning of the first chapter, "The education of the architect" (Book I): "The architect should be equipped with knowledge of many branches of study and varied kinds of learning, for it is by his judgment that all work done by the other arts is put to test." Vituvius, The Ten Books of Architecture (Mineola, N.Y: Dover, 1960), 5. 
coincidences are only random effects [...].", We would add that, for example, music, the art form considered by many to be closest to architecture (*architecture and music), does not have a history that is at all close to that of architecture.

Our approach makes no claim as to originality; it is firmly integrated in current contemporary thought. Since the late 1970s architecture has fervently sought connections with other fields of art. As Juhani Pallasmaa states: "This frantic interest in expanding the scope of architectural thought clearly indicates that the art of architecture has become uncertain of its essence and future course."3

Interdisciplinary research refers to the reciprocal exchange of information and comparative studies while transdisciplinary research implies integration and the elimination of scientific borders. Transdisciplinary means, as Basarab Nicolescu, whose theories inspire us, argues: "to celebrate the transgression of disciplinary boundaries."

\section{Interrelating Disciplines}

\section{Architecture and Music}

Architecture and music have been connected since antiquity, so much so that one can say that the connection can be considered a tradition. It was the discoveries of Pythagoras, for whom numbers governed the universe of sound in its physical logic and regulated in it is artistic organization that conferred this special nature on music. We must point out that when we speak of music herein, we are referring to theoretical music, to harmony. An idea disseminated from the Middle Ages to Modernity, where, under the guidance of Humanism, it took on new and structured life. ${ }^{5}$

It was the harmonic proportion of the Greek musical scale determined from the simple consonances - 1:2 (octave), 2:3 (the perfect fifth) and 3:4 (the perfect fourth) - and the geometric $-a / b=b / c$ or $b=\sqrt{a c}-$, the arithmetic $-a-b=b-c$ or $\mathrm{b}=(\mathrm{a}+\mathrm{c}) / 2-$, and harmonic $-(\mathrm{a}-\mathrm{b}) / \mathrm{a}=(\mathrm{b}-\mathrm{c}) / \mathrm{c}$ or $\mathrm{b}=2 \mathrm{ac} /(\mathrm{a}+\mathrm{c})-$ means that were to strongly influence architectural theory and practice during the Renaissance.

Although by no means decisive for the architect's privileged status, particularly during the Renaissance with the likes of Alberti (1404-1472) and Palladio (1508-1580), Vitruvius already does refer to the importance of musical

2. A. Picon, A. and A. Ponte, "Introduction," in Architecture and the Sciences: Exchanging Metaphors (New York: Princeton Architectural Press, 2003), 16.

3. J. Pallasmaa, The Architecture of Image: Existential Space in Cinema (Helsinki: Rakennustieto, 2001), 13.

4. Basarab Nicolescu explaining the first appearance of the term transdisciplinarity - going beyond multidisciplinary and interdisciplinary approaches - almost simultaneously in the 1970s in the works of Jean Piaget, Edgar Morin and Erich Jantsch as a response to a then-perceived need. In B. Nicolescu, Manifesto of Transdisciplinarity (New York: State University of New York, 2002), 1. See also M. Cazenave and B. Ed Cient Nicolescu, L'homme, la science et la nature: regards transdisciplinaires (Aix-en-Provence: Le Mail, 1994) and B. Ed. Nicolescu, Transdisciplinarity: Theory and Practice (Cresskill, NJ: Hampton Press, 2008).

5. See, on music and architecture, generally, C. G. Gonçalves, Arquitectura: diálogos com a música: concepção, criação, tradição (Sevilla: ETSA/Universidad de Sevilla, 2008). 
knowledge for an architect.

Following this tradition, the work of Boethius (ca.480-524), a disciple of St. Augustine (354-430), De Institutione musica (published in Venice in 1491-92), which was a fundamental text during the Middle Ages, retained its importance during the Renaissance. It brought to the Middle Ages the philosophy of proportions in its original Pythagorean conception, developing a theory of proportional relationships in the context of musical theory. And it was through Boethius, that Pythagoras came to be recognized in the Middle Ages as the inventor of music. Boethius defined a very characteristic and representative aspect of the mediaeval mentality - an attitude that was to be fundamentally important for the advent of Humanism and Renaissance architectural theories. When he spoke of music Boethius was thinking of a mathematical science of musical laws. ${ }^{6}$

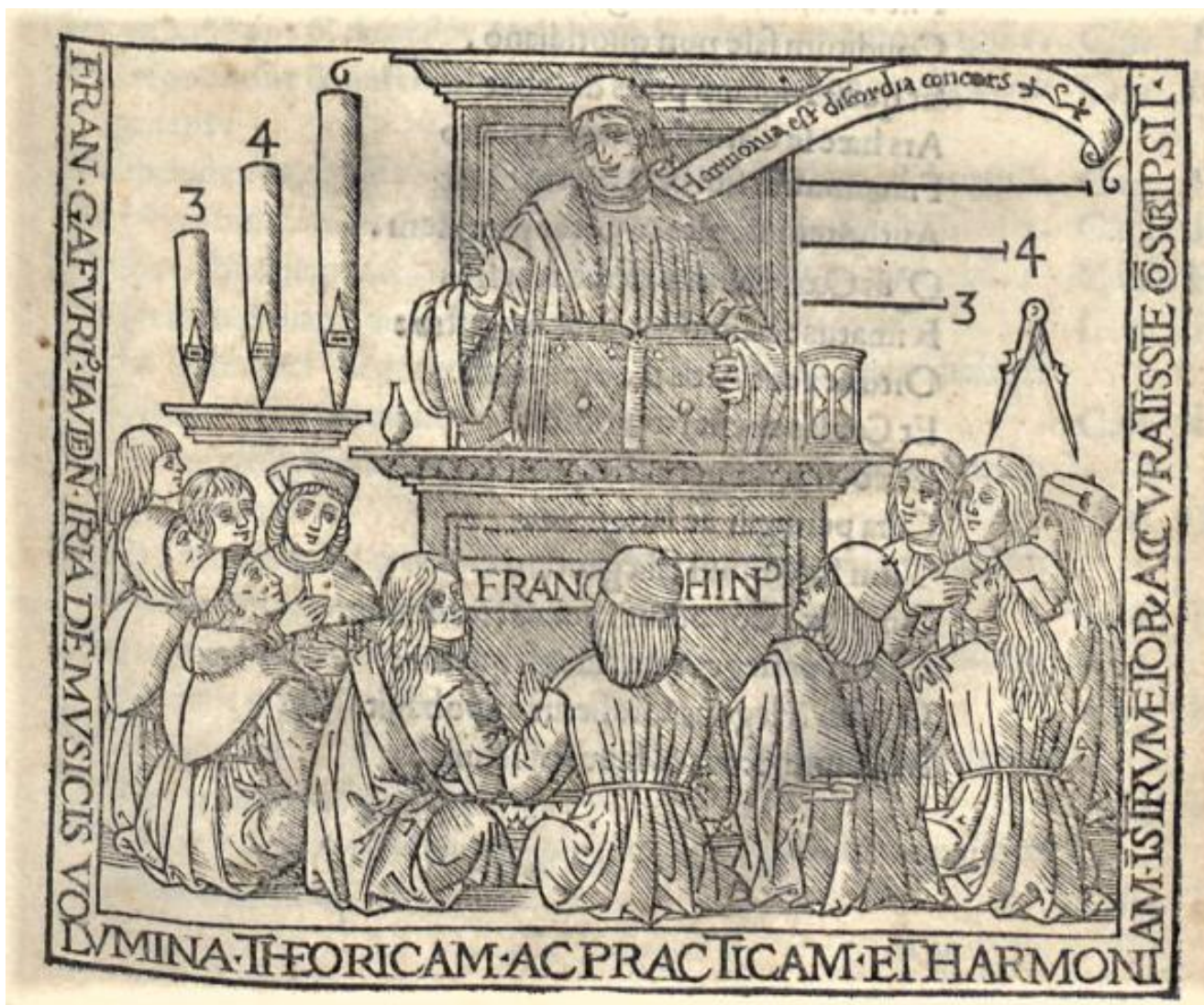

Figure 1. Franchino Gafurio (1451-1522), the Famous Renaissance Musical Theorist, Lecturing. From Franchino Gafurio, De Harmonia Musicorum Instrumentorum, 1518

(On the left, three organ pipes of 3, 4 and 6 lengths, illustrating the ratios of the octave divided by the harmonic mean 4 into fourth and fifth; on the right, the three lines repeating the ratios 3, 4 and 6 and the dividers state that musical harmony is geometry translated into sound).

Source: BnF.

During the Renaissance, the music-architecture relationship was underpinned 1989).

6. See, for example: U. Eco, Arte e beleza na estética medieval (Lisboa: Editorial Presença, 
by several treatises. In his De re aedificatoria (1485), Alberti advocates the use of harmonic proportion by architects, arguing that musicians were true specialists on harmony present in nature (Figure 1). In his Quattro Libri (1579), Palladio recommends the use of harmonic proportions in drawing up the plans for rooms and the use of arithmetic, geometric and harmonic progressions to determine the three dimensions of a room. He applied these principles to his own design projects, such as Villa Godi (1537-42) and Villa Malcontenta (1559-60). ${ }^{7}$

This line of thought continued even after the rupture introduced by Claude Perrault (1613-88) and the acceptance of the architect's taste or intuition. Authors such as Charles-Étienne Briseux (1660-1754) who, taking inspiration from JeanPhilippe Rameau (1683-1764), maintained that there were proportions that were beautiful a priori - divine numerical relationships - kept the flame of tradition alive. Despite his contemporary followers and his considerable posthumous influence, after Perrault mathematics continued to fascinate and dominate, and for this reason music retained its ascendant position in terms of influence on architecture. $^{8}$

In the Modernist scenario of the $20^{\text {th }}$ century, the approximation between architecture and music was felt in diverse areas. In the visual arts (which in this period accompanied architecture hand in hand, with training taking place in the same schools), a considerable process of approximation to music took place. ${ }^{9}$ However, one must also point out that, at the Bauhaus, music did not occupy a prominent position. Indeed, it did not exist in the various study plans, even if composers such as Paul Hindemith (1895-1963) became involved in diverse projects, such as his collaboration on Oskar Schlemmer's (1888-43) Das Triadische Ballet. ${ }^{10}$ One should also mention here that Schlemmer's take on dance was not so much a "ballet" as a spatial study. Maybe we're looking into a paradox: although architecture and the plastic arts have shared a common path the presence of music was most evident in the plastic arts.

Towards the end of the $20^{\text {th }}$ century a number of authors made reference to the relationship between architecture and music. Some, like Steven Holl (b. 1947), links architecture to a holistic world, referencing the long-standing interdisciplinary relationship and alluding to Kepler. Daniel Libeskind (b. 1946) writes of music being close to architecture and also uses it as a tool in his design projects. Marcos Novak (b. 1957) rejected the "Pythagorean" character favoured by Xenakis and created, by means of the digital world, a new interdisciplinary relationship between architecture and music based on computing. This will lead eventually to "archimusic" - the fusion of both disciplines. According to Marcos

7. Along with Wittkower's classic: R. Wittkower, Architectural Principles in the Age of Humanism (London: Academy Editions, 1998,) see for example: D. Howard, "Harmonic proportion and Palladio's Quattro Libri,” Journal of the Society of Architectural Historians XLI, 2 (May 1982), 116-146.

8. See, for example: Pérez-Gómez, Charles-Etienne Briseux's musical analogy and the limits of instrumentality in architecture.

9. See, for example: J. Dir. Arnaldo, Analogias musicales: Kandinsky y sus contemporaneos (Madrid: Exhibition catalog. Fundacion Colleccion Thyssen-Bornemisza), 2003.

10. See, for example: C. Jewitt, "Music at the Bauhaus: 1919-1933," Tempo 213 (July 2000), $5-11$. 
Novak, "music has reinvented itself in far more profound ways than architecture has dared" and should therefore be an example to architecture. ${ }^{11}$

One should emphasize the idea that most of the times it was architecture - or architects - that sought out music and not the other way round. This contrasts with the relationship between architecture and dance (*architecture and dance).

Despite this nod to music by architecture and the extensive references to the proximity between the two throughout history, architecture has traditionally been included in histories of fine art (together with painting and sculpture). The BeauxArts dominated, despite everything. What does this tell us? That the more abstract aspect lost out to the more visual one?

It must be stressed as well, and relating to these aspects, that one of the more often refereed issues on comparing both disciplines is the fact that both architecture and music need a precious representation to their respective put into practice. We may establish as comparable: the process - architectural design and composition - and the record - drawing and score. This record implies the existence of a notation system. (*Notation) (This does not exist with painting or sculpture.)

\section{Harmony}

Whilst harmony does not have a meaning in architecture as precise as it is in music, an analysis of the concept of harmony in itself reveals the common roots of the two disciplines. In western musical tradition harmony governs the progression of the chords in a piece of music. Despite its meaning being now obsolete, it is fundamental as it is at the root of western musical tradition. Up to the early $20^{\text {th }}$ century, harmony was understood as the mechanism that structures a whole piece of music, on which the tonal system is based. Harmony in architecture (making the analogy to classical thought) likewise points to a coherent and complete relationship between the individual parts and between the parts and the whole.

\section{Harmony and Melody/Proportion and Design}

In the classical tradition, proportion enables and guarantees the relationship between all the parts and between the parts and the whole, allowing the object to become a cohesive whole. This is true for architecture. This is true for music.

In reflecting on the academic complementarity between harmony - as the horizontal character - and melody - the vertical character - in music, a very interesting look is proposed by Raul Lino ${ }^{12}$ (1879-1974) who proposes the analogy between the musical correspondence between harmony and melody and the architectural correspondence between proportion and design. Besides this point that helps in looking at a building identifying its "melody" (an aspect that seems easier in music) - the same in music it is only possible to sing the melody and not

11. M. Novak, "Breaking the Cage," in Pamphlet Architecture. Architecture as a ranslation of music (ed.) Martin, E. (1994), 69. 1947).

12. R. Lino, Quatro palavras sobre Arquitectura e Música (Lisboa: Valentim de Carvalho, 
the harmony - it is also a symptomatic approach in interdisciplinary relation for it is not visually based.

\section{Matter and Sound}

This pair of concepts is fundamental in the relationship between architecture and music, given that music proceeds from the sound, conferring qualities upon it, and architecture proceeds from matter, and confers certain qualities upon it. In this sense, the two disciplines function analogously. However, one must highlight the fact that that is no equivalent term for "sound" in architecture (music is composed with sounds). What we call matter - or material - does not correspond precisely to sound, as in the sound elements used to compose music. There is no term for the spatial element with which we design. What is "matter" in architecture?

\section{Full/Void and Sound/Silence}

Just as in architecture matter is made visible also by the void in between, in music, too, the sounds are distinguished from each other by the silence between them. Thus, the void and the silence are part of the respective compositions.

We can use music in order to look at architecture. If we consider three types of silence in music as proposed by Jean-Jacques Nattiez ${ }^{13}$ - silence considered as musical work, silence as used in the classical tradition in order to create expectations and silence considered as a value in itself since modern music - we can easily find three different kind of voids: the void resulting of functional issues, the void stressing existing forms and the void considered in itself.

\section{Architecture and Mathematics}

We can say that the importance of mathematics is on the basis of the tradition between architecture and music. And that the tradition that links architecture and mathematics is at the basis of a number of principles to be found in classical thought of the western tradition.

This Pythagorean-Platonic tradition was to form the basis of and define a number of ideas associated with what one could call classic thought in architecture - that begins in antiquity and continues uninterrupted throughout the Middle Ages. It is thought that is founded on the desire to follow Universal Order (initially with God, and later with or without Him) in the work of art: to build a microcosm after the image of the macrocosm, interconnecting, through proportion and mathematical structuring, man, architecture and the universe; the desire to represent, through mathematics, that connection between man, architecture and the universe.

It is important to note that during the Renaissance, in particular with the emergence of the Scientific Revolution, mathematics retained and expanded its special status - mathematics provided the proof of things. Mathematics meant

13. J.-J. Nattiez, "Som/ruído," in Enciclopedia Einaudi (ed.) Romano, R. Dir., vol. 3 (ArtesTonal/atonal) (Lisboa: Imprensa Nacional - Casa da Moeda. 1984), 213-214. 
truth. One should also note that science - or natural philosophy, at that time - was imbued with the same spirit, and the discourses of scientists such as Kepler (15711630) shared the same ideas.

The belief in the world's mathematical structure is a strong issue among several authors, according and along with the emergence of abstraction in the modern art: we can mention, still in the nineteenth century, Adolf Zeising (18101876)'s Der goldene Schnitt (1884). Matila Gkyka (1881-1965) is an unavoidable name whose works strongly influenced the subsequent generations. We can mention Esthétique des proportions dans la nature et dans les arts (1927) and Le nombre d'or: Rites et rythmes pythagoriciens dans le development de la civilisation occidentale (1931) which preface is written by Paul Valéry - who spend decades studying mathematics and whose Eupalinos (1921) celebrates the proximity between architecture and music - and translated into English as The Geometry of Art and Life (1946). We must also call into question the fact that Matila Ghyka was a close friend to Le Corbusier whose drawings (namely for Brussels Pavilion) frequently remind Ghyka's. ${ }^{14}$ This influence is still strong during the 1950s.

\section{Architecture, Music and Mathematics}

Given music's highly mathematical nature, its mathematical genesis, the architecture-music-mathematics relationship inherited that same tradition. One could even say that the relationship between music and mathematics is the backbone of the architecture-music-mathematics relationship. Again this is a tradition that has continued uninterrupted since antiquity.

Still in the $20^{\text {th }}$ century many ideas were inspired by these theories, with Le Corbusier, for example, becoming a paradigmatic figure. The mathematicsarchitecture and mathematics-architecture-music relationships were fundamentally important in his thought process. Mathematics and music lived in his idea of architecture. The presence of mathematics presupposes the connection to music and vice-versa, encompassing a number of values that emanate from the tradition. He used the Modulor to maintain the ancient links between man, nature and architecture, based on the mathematic structuring of architecture using proportion.

In this sense, the Modulor represents a synthesis of Le Corbusier's thought. First of all, the name itself alludes to the module and the golden ratio. Moreover, measurement, harmony, universality and mechanics - four concepts closely related with order and transversal to history and to each other - are referenced in the first volume Le Corbusier wrote on his concept. One can take two different approaches to the Modulor: an interpretation of the books Le Modulor: essai sur une mesure harmonique a l'échelle humaine applicable universellement a l'architecture et a la mécanique (1948) and Modulor 2: 1955 (La parole est aux usagers) suite de "le Modulor" "1948" (1955); and using the Modulor as a design tool.

The following aspects become clear in the former approach: the importance of 2003).

14. See, for example: R. Masiero, Estética de la Arquitectura (Madrid: Machado Libros, 
mathematics and its relationship with architecture; music and its relationship with mathematics and architecture; the idea of nature as a mathematical construct; the allusion to mimesis; the importance of the (mathematical) order of the world. And in the latter approach: seeing it as a means of putting theoretical aspects into practice, one can understand the Modulor as a means of conceiving the architectural object in a single system of proportions, allowing the parts to relate to each other and with the whole in the same way; considering the object as an organic unit; the similarity between man, nature and architecture, which is so evident in the drawings that represent it, in particular the versions that immediately recall the numerous Renaissance interpretations of the Vitruvian man.

Le Corbusier's thought presents itself in the $20^{\text {th }}$ century as a memory of an old and omni-present tradition that is conscious of its search for the human in communion with the cosmos, through mathematics. ${ }^{15}$

We can look back in time and find Kepler's ideas again. In Harmonices Mundi (1619), in addition to these studies of the solids and regular polyhedra, he also applies the harmonic proportions to his model of the universe and the movement of the planets: each planet's distance from the sun is calculated on the basis of harmonic proportions. Kepler argued that harmonic proportions should dominate the whole object, ensuring a coherent relationship between the various parts and between the parts and the whole, so that the object is an organic unit. By moving, the planets emit sounds that together create the Music of Spheres. That music, produced by the planets, can only be heard from the Sun. Proportions must be taken from music - music is inherent to nature. For Kepler, music "is not a human invention, subject as such to change, but a construction that is so rational and natural that God the Creator has impressed it upon the relations of the celestial movements." 16

\section{Architecture, Music and Cosmology}

Architecture shares the same mathematical principles as cosmology. They are both founded on philosophy and mathematics. One should note that music was part of the quadrivium, together with arithmetic, geometry and astronomy.

The importance of music and its connection to mathematics is so great that it influenced, amongst other things, Kepler's cosmology. In Mysterium cosmographicum (1596), Kepler establishes a model for the universe based on the five Platonic solids enclosed by a system of concentric spheres (Figure 2). He also believed that there were only six planets (the known planets at that time), as there were only five Platonic solids, five regular polyhedra.

15. See C. G. Gonçalves and M. J. Soares, "Le Corbusier: architecture, music, mathematics: longing for classicism?"' in Le Corbusier: 50 años después (ed.) J. T. Dir Cueco and Vallejo C. Coord Mejía (València: Editorial Universitat Politècnica de València, 2015).

16. Cited in A. Pérez-Gómez, Charles-Etienne Briseux's musical analogy and the limits of instrumentality in architecture (Nebraska: The University of Nebraska-Lincoln, 1999), 29. 


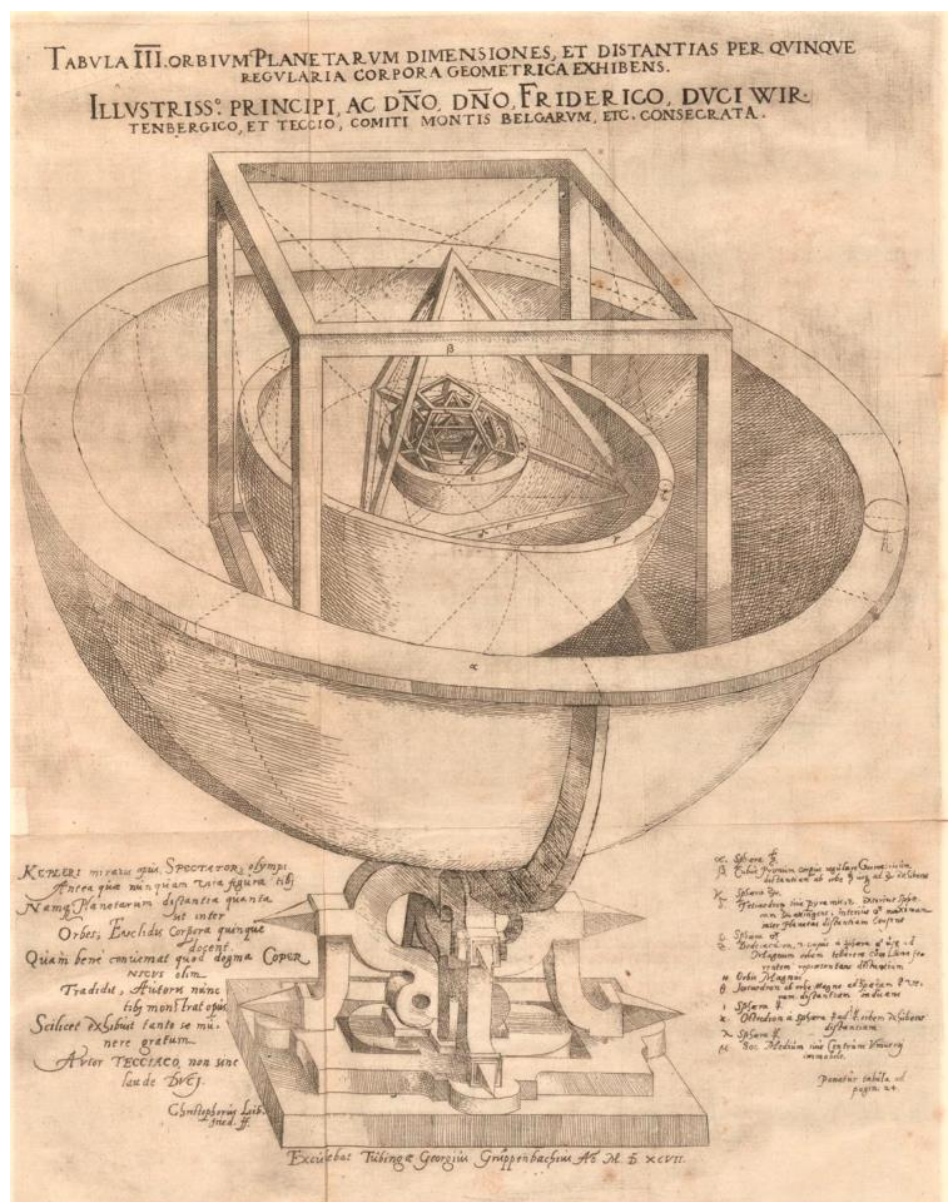

Figure 2. The Model of the World Proposed by Kepler based on the Five Platonic Solids. From Johannes Kepler, Mysterium Cosmographicum, 1596.

Source: www.e-rara.ch.

One can look at Kepler's cosmological model as an architectural model: as the cosmological geometry of the ideal dwelling. A model of the cosmos, the ideal dwelling, mathematics, laws and forms, numbers and figures, arithmetic and geometry. Or, following Richard Padovan's line of argument: Kepler's work can only be understood in line with a vision of the world as purely physical as it is religious and aesthetic. ${ }^{17}$ Kepler also treated the universe (and he was the last to do so) not only as a mechanism but as a divine work of art: as a "magnificent temple", a gigantic architectural construct governed by geometry and mathematical proportion. For Kepler, whose world had been created by God as one enormous harmony, a mathematically ordered whole in which things were to be determined and inter-related mathematically, numbers and measurements could not be arbitrary and separate facts but were intimately connected (as they were for Plato) by proportion. ${ }^{18}$ This could be an architect's reasoning. ${ }^{19}$

17. R. Padovan, Proportion: Science, Philosophy, Architecture (New York: Spon Press, 2003), 247.

18. Ibid, 247-248.

19. See C. G. Gonçalves, "The perfect dwelling is any place in the heavens: Platonism, 


\section{The Idea of Organism}

This is an idea that dominates renaissance's architecture doctrine, which is strongly based on the special status of mathematics and it indeed fascinating for its transversal presence in every discipline. (*Architecture and mathematics)

Edward E. Lowinsky points out that from Copernicus (1473-1543) onwards the minds of both the musician and the astronomer seem to have turned towards the concept of organic unity. Copernicus considered his new theory as a way that could establish: "the order and magnitudes of all the planets and of their spheres or orbital circles and it would bind the heavens together so closely that nothing could be transposed in any part of them without disrupting the remaining parts and the universe as a whole." 20 For Copernicus, as after for Kepler, the idea of the symmetrical harmony of the universe, of its form as a giant, coherent and wellproportioned body, was of vital importance. ${ }^{21}$ This idea of an organism which could be provided by proportion was also advanced by Zarlino (1517-1590), who introduced the definition of a "corpo" for polyphonic music, now regarded as "a body, as one coherent organism". "This aspect is also evident in the architectural discourse. Bramante's (1444-1514) plan for St. Peter's Basilica, for example, is for Rudolf Wittkower ${ }^{23}$ the supreme example of organic geometry, that type of proportionally integrated "spatial mathematics" that became a distinctive aspect of the Humanist architecture of the Renaissance. Palladio who in the latter's Quattro Libri recommends and shows his own use of harmonic proportions defines beauty thusly: "Beauty will result from the beautiful form and from the correspondence of the whole to the parts, of the parts amongst themselves, and of these again to the whole [...]. ${ }^{, 24}$ Every description on the theme echo Alberti's discourse on beauty. Should we call for Le Corbusier's ideas?

\section{Architecture and Dance}

Dance shares with architecture the fact that it works with the human body; the body, space and time. The body that moves in the space and time. However, one must bear in mind that the body that dances is not that of the architect; the architect's body is the common body, not the body that embraces the composed movement - the body of dance. Whereas space is the protagonist in architecture, in dance it is the body. But this protagonism of space and body has not always been evenly balanced. ${ }^{25}$

mathematics and music: on Kepler's thought and the theory of architecture in the Renaissance," in Proceedings of the 2th International Multidisciplinary Congress: PHI 2016 -Utopia(s) - Worlds and Frontiers of the Imaginary. (ed.) Monteiro et al. (London: CRC Press, 2017).

20. E. E. Lowinsky, "The concept of physical and musical space in the Renaissance," in Music in the Culture of the Renaissance and Other Essays (Chicago: The University of Chicago Press, 1989), 71.

21. Ibid, 60 .

22. Ibid, 73 .

23. Wittkower, Architectural Principles in the Age of Humanism, 1998, 34.

24. Ibid, 31.

25. See, on architecture and dance generally, M. J. Soares, Para uma medida da arquitectura 
Throughout the history of dance the relationship with the space - the body in movement in a space - has been anything but constant. Whilst in the $17^{\text {th }}$ century (the period of the Court Ballet, so characteristic of the court of Louis XIV), social dancing differed little from theatrical and artistic dancing, from then onwards social dance and theatrical dance grew further and further apart until the advent of $19^{\text {th }}$-century ballet, when the two forms became totally distinct realities. Later, Merce Cunningham (1919-2009), amongst others, developed dance in a nontheatrical performance space. Is that specific form of dance, taking place off the stage, not a step backwards in time? Placing dance's space closer to architecture's space.

The relationship with the space also emerges in another aspect: the space occupied by the human body in movement. Here the analysis of Rudolf Laban (1879-1958) is of particular interest. Laban conceived movements of the body inside an icosahedron, where the dancer is located. He also added a cube and an octahedron to the icosahedron. The dancer's movements correspond to the edges of the solid. This must, of course, be compared to Kepler's cosmological theory (*architecture, music and cosmology) and the interest in Platonic geometry or other proportion systems which are confirmed by history and also met with obvious fascination in avant-garde circles. (*architecture and mathematics)

In architecture, Le Corbusier's promenade proposal committed to this presence of the body, but perhaps before this all the court rituals and movement of the body and bodies together, which together with the costumes, lived in the Baroque spaces in syntony, had been forgotten...

Although, on one hand, the ballet of the $18^{\text {th }}$ and $19^{\text {th }}$ centuries introduced this barrier between two different kind of spaces - the lived one and the performing one -, on the other hand, it introduced a new development that was directly related with architecture: the pointe ballet shoe, the purpose of which was to obscure gravity. By acceptance, or by challenge, both in conception and execution, gravity is a fundamental aspect of both disciplines. This is not the case for cinema, for example (*architecture and cinema). And this is a major subject of discussion. Isadora Duncan (1877-1927), imbued with modernist spirit, came out against this and other aspects of dance, performing barefoot. Martha Graham (1894-1991) went much further, encouraging movements in which the dancers were not only barefoot, but also made full contact with the floor. Graham made this modern development introduced by Isadora Duncan and others a tradition, dismantling the classical principles of dance and using the space as an element of reaction to the body's movement.

At the Bauhaus, a fundamental setting for conception and experimentation in modern architecture, dance played a greater role than music (*architecture and music). It was the central-European art theories advanced by Hildebrand (18471921), Schmarsow (1853-1936) and Alois Riegl (1858-1905) that were the first to highlight the role of space in architecture and to introduce the idea of movement as a fundamental aspect of fruition of an art work. Even if Das Triadische Ballet can be regarded more as an exploration of spatiality than a "ballet", its theme was space and the body.

(Lisboa: Universidade Lusíada. 2004). 
From the late $20^{\text {th }}$ century onwards a number of dancers and choreographers began to explore a dual disciplinary approach in concrete works. The last twenty years has seen a proliferation of choreographies exploring essentially architectural themes. There is also the two-pronged approach of choreographers who are interested in architectural themes, but also co-authorship works. ${ }^{26}$

Alongside choreographers' interest in architecture, interest in the city as a theme also emerged. Frederic Flamand (b.1946), a choreographer who explores architecture and the city in his works, writes: "Architecture is not just constructing buildings. That notion changes when one thinks of architecture as an art, as an aesthetic, as a discipline that interacts with the space, with life and, consequently, with dance. I like the idea of creating a space occupied by dancers and confronting it with the idea of an architectural space lived in by people. In this sense, Metapolis (2000) is intended as a psychological journey into the ways spaces influence bodies." 27

In this sense, one could argue that the Baroque space - the epitome of the staged scene - or even spaces that have served for ritual activities since time immemorial are closer to this idea than contemporary space, for example.

A fundamental aspect common to both disciplines is notation, also a common element of architecture and music (*architecture and music; *notation).

\section{Notation}

Notation is associated with the idea of representation. The need for previous representation and the existence of drawings and score if frequently argued for the proximity between architecture and music. (*Architecture and music)

But as a subject not as developed as architectural drawing/music score similarity, as far as notation is concerned, the history of dance has seen the development of diverse codifications since the Renaissance. The composers of the Baroque courts standardised movement by means of the drawing of paths on the floor. In addition to these mapped paths, figures showing the steps were used. This codification, which was introduced by Pierre Beauchamp (1636-1705), can be considered the first notation system for dance (Figure 3).

26. M. A. Alejandre, El espacio sin-fín: una mirada a través del cuerpo: traslaciones entre danza y arquitectura (Sevilla: Universidad de Sevilla, 2015).

27. Ibid, 22. 


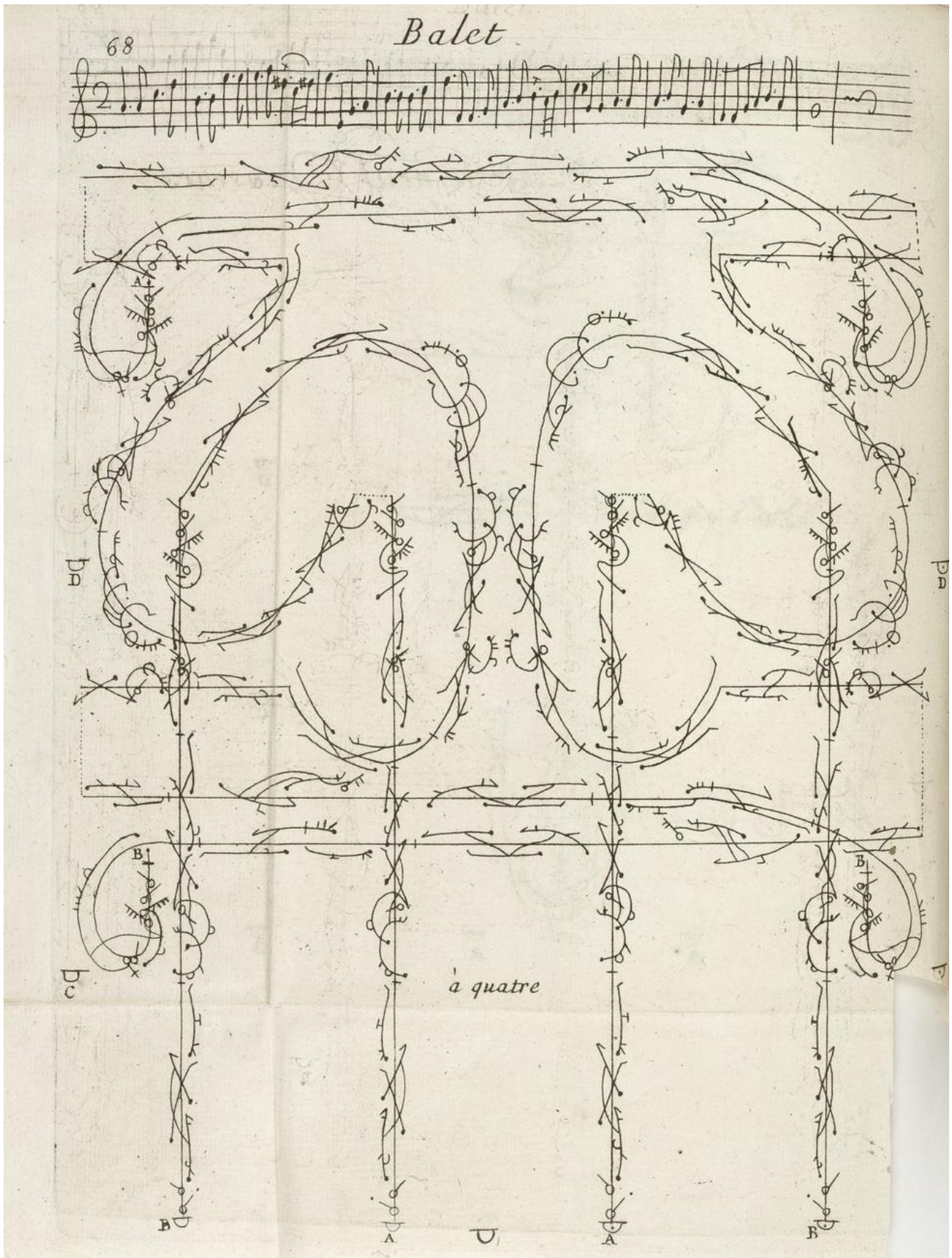

Figure 3. A Dance Recorded in Notation. From Raoul-Auger Feuillet, Recueil de Dances Composées par M. Feuillet, 1700

(Although it was Pierre Beauchamp - considered the first choreographer of the Paris Opéra and the inventor of the five basic positions of the feet -, who first devised a system of dance notation, he never published such system. It was one of his pupils, Raoul-Auger Feuillet (c.1675-c.1710), who published, in 1700, Chorégraphie ou l'art de décrire la danse [Choreography, or the Art of Describing the Dance], one of the earliest published systems of dance notation. He also published several other works based on this notation (as the one shown here)).

Source: BnF. 
The most complete notation system developed so far is Labanotation, named after its creator, Rudolf Laban. ${ }^{28}$ It is the first notation system which, in addition to being conceived as an alphabet rather than a register of completed movements, also contained information on duration, fluency and intensity of movement. This is a particularly interesting aspect when it comes to architectural design, given that the conventional drawing does not include spatial qualities per se. It is perhaps no coincidence that Laban studied architecture and philosophy (in Paris). It is conceivable that his interest in architecture led him to his analysis of movement in spatial structure. $^{29}$

\section{Architecture and Cinema}

The relationship between architecture and cinema was established from the outset, considering that cinema works with and in spaces, from the urban scale to the tiniest spaces - be they real or imaginary, built or virtual. Another aspect was the fact that the image was fundamental to both. Cinema always presents reality from a specific perspective. And in this sense, one can see cinema as one more way of representing architecture, given that cinema often gives us a particular perspective on reality that would be physically impossible for the viewer. In the words of Luis Buñuel (1900-83): "the movies will be the faithful translator of the architect's boldest dreams". ${ }^{30}$ Furthermore, Robert Mallet-Stevens (1886-1945), who worked in both forms of expression, stated: "[...] architecture does not only serve the cinematographic set (décor), but [...] architecture 'plays'."31 Today, thanks to the possibilities provided by the new technologies (video, virtual reality, etc.), architecture frequently melds with cinema.

The fascination architects have had, and still have today, with cinema is beyond question. According to Pallasmaa, in many schools of architecture around the world today cinema is the newest interest. ${ }^{32}$ This can be attributed to its great proximity (the greatest of all proximities between disciplines, according to Pallasmaa) with cinema: "In its inherent abstractness, music has historically been regarded as the art form which is closest to architecture. Cinema is, however, even closer to architecture than music, not solely because of its temporal and spatial structure, but fundamentally because both architecture and cinema articulate lived space. These two art forms create and mediate comprehensive images of life"33 (*architecture and music). This point is extremely interesting and offers an insight not only into human output (artifice) in general, but also into what architecture is or, at least, what is per se more important, in particular. It also pitches two opposing worlds against each other in architecture since the beginning: an

28. See A. H. Guest, Labanotation: The System of Analyzing and Recording Movement (New York, NY: Routledge, 1987).

29. See Soares, Para uma medida da arquitectura, 2004.

30. Luis Buñuel cited in M. Teixeira, "Arquitectura e cinema," in Cinema e arquitectura (ed.) A. Dir. Rodrigues (Lisboa: Cinemateca Portuguesa, 1999), 32.

31. R. Mallet-Stevens, "O cinema e as artes: a arquitectura," in Cinema e arquitectura (ed.) A. Dir. Rodrigues (Lisboa: Cinemateca Portuguesa, 1999), 95.

32. Pallasmaa, The Architecture of Image: Existential Space in Cinema, 2001, 13.

33. Ibid, 13. 
idealized, full, ordered world and another world which, proceeding from that, or not, is humanized in its imperfections and singularities. Pallasmaa refers to this thusly: "Houses are built in the world of Euclidian geometry, but lived space always transcends the rules of geometry. [...] Lived space is always a combination of external space and inner mental space, actuality and mental projection." ${ }^{34}$

Given that cinema is a recent art, its process of approximation to architecture naturally proceeded from the $20^{\text {th }}$ century avant-garde. From the very beginning architecture and film shared the same spirit. Expressionism was one of the most fruitful periods in exploring the relationship between architecture and cinema, with said exploration manifesting itself in Expressionist films, such as Murnau's Nosferatu (1922). Cinema and modern architecture thus asserted themselves concurrently. Robert Mallet-Stevens argues: "It is undeniable that the cinema has a marked influence on modern architecture; in turn, modern architecture brings its artistic side to the cinema." 35 Paradigmatic examples of this development are Mallet-Stevens' Villa Noailles (1923-1927) (Figure 4), Le Corbusier's Villa Savoye (1928-1930) and Adolf Loos' Villa Müller (1928-1930). ${ }^{36}$

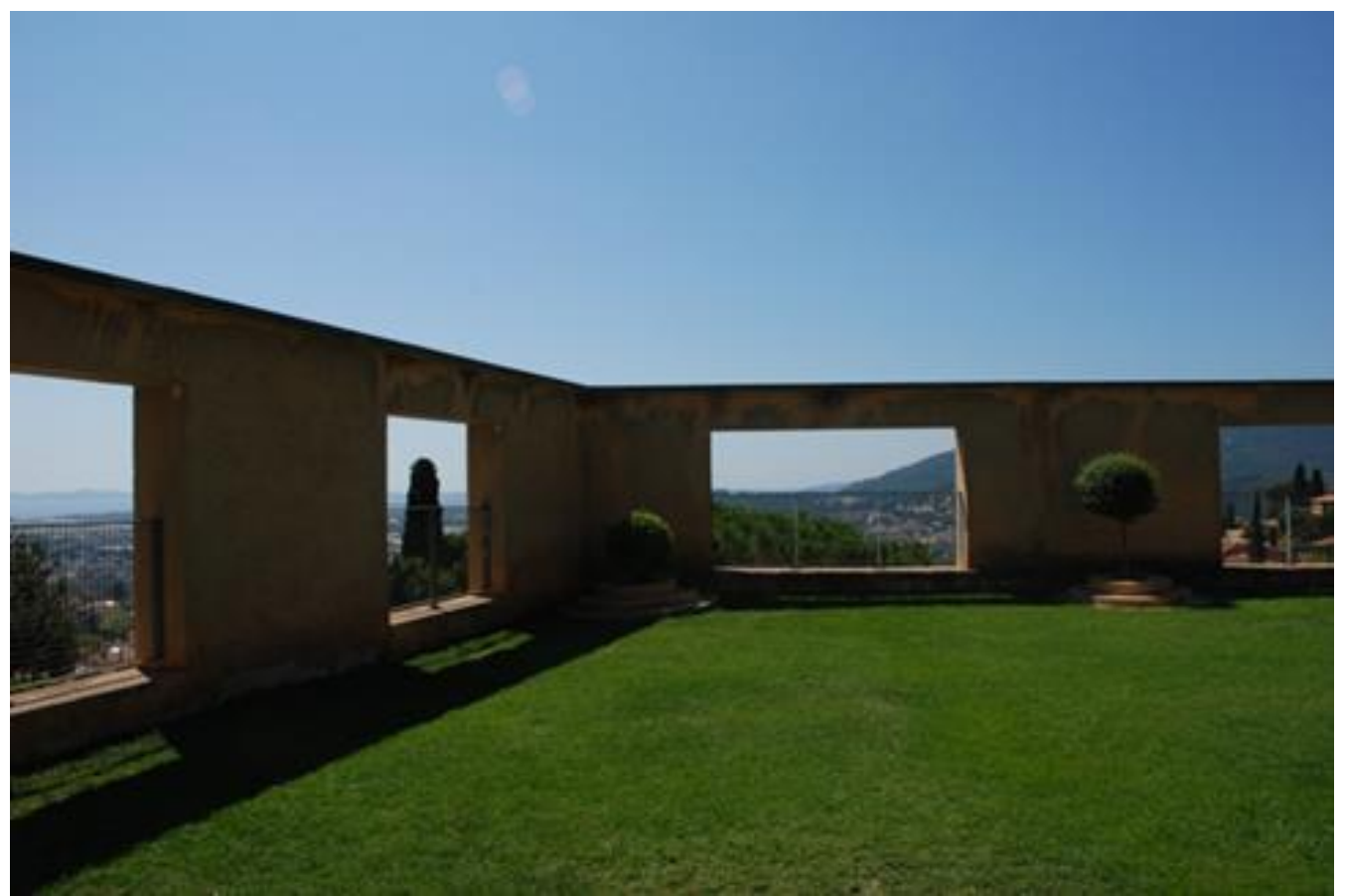

Figure 4. Robert Mallet-Stevens, Villa Noailles, Hyères, France, 1923-1927

Source: Susana Tavares dos Santos.

Another aspect examined and explored by architecture and film was the city. If it is true that cinema made urban life and the city itself one of its themes of choice, it is no less true that our imagination adopted images of cities based on cinematographic suggestions (*architecture and dance). Cinema portrayed urban

34. Ibid, 18.

35. Mallet-Stevens, "O cinema e as artes: a arquitectura," 1999, 95.

36. S. T. S. Henriques, A influência do cinema na arquitectura europeia: dos anos 10 aos anos 30 do século XX (Lisboa, Universidade Lusíada, 2012). 
reality in a range of ways: from more pessimistic stances, as in Metropolis (Fritz Lang, 1927) to ironic takes, as in Mon oncle (Tati, 1958). The disenchantment of architectural thought in the post-war period was also mirrored in the cinema. By the 1990s the thematic and stylistic multiplicity was very visible in the two art forms.

\section{Conclusions}

While elaborating this approach for the future dictionary it already evidences that a clear traditional/hierarchical systematization is quite difficult, if to say, impossible to establish. Relations and different kinds of relation can be established in multiple directions.

Another idea that emerges is that despite on the traditional literature on this type of subject in practice different authors and circumstances go counter-current. This is evident in the fact that the traditionally and always still present triad architecture-painting-sculpture is so far away in most of the examples explored and still to be explored. And each different relationship that is established appears as a paradigmatic reasoning for the period in which it emerges. For instance, the fact that, during the Renaissance, harmonic principles should be incorporated in architecture and not the other way around, shows that a specific method is imposed from one discipline into another, establishing an interdisciplinary relationship.

But the contemporary need for transdisciplinarity rather than interdisciplinarity (following Cazenave and Nicolescu, L'Homme, la science et la nature) is in consonance with the non-hierarchical view of today's vision on the various disciplines. Today, other disciplines serve as examples, rather than as models. While this is true, it is also true that (as is the case of Le Corbusier) a nostalgia for a classical dominance of mathematics is felt. But even in this case this nostalgia may be identified with the fact that transdisciplinarity and transcendence are profoundly linked (following Cazenave and Nicolescu, L'Homme, la science et la nature).

\section{Acknowledgments}

This paper was funded by National Funds through the FCT - Foundation for Science and Technology, under the Project UID/AUR/04026/2013.

\section{Bibliography}

Alejandre, M. A. El espacio sin-fín: una mirada a través del cuerpo: traslaciones entre danza y arquitectura [The sinfín space: a look through the body: translations between dance and architecture.] Sevilla: Universidad de Sevilla, 2015.

Arnaldo, J. Dir. Analogias musicales: Kandinsky y sus contemporaneos [Musical analogies: Kandinsky and his contemporaries.] Madrid: Exhibition catalog. Fundacion Colleccion Thyssen-Bornemisza, 2003. 
Cazenave, M. and B. Ed Cient Nicolescu. L'homme, la science et la nature: regards transdisciplinaires [Man, Science and Nature: Transdisciplinary Eyes.] Aix-enProvence: Le Mail, 1994.

Eco, U. Arte e beleza na estética medieval [Art and beauty in medieval aesthetics.] Lisboa: Editorial Presença, 1989.

Gonçalves, C. G. Arquitectura: diálogos com a música: concepção, criação, tradição [Architecture: dialogues with music: conception, creation, tradition.] Sevilla: ETSA/ Universidad de Sevilla, 2008.

Gonçalves, C. G. "The perfect dwelling is any place in the heavens: Platonism, mathematics and music: on Kepler's thought and the theory of architecture in the Renaissance." In Proceedings of the 2th International Multidisciplinary Congress: PHI 2016 -Utopia(s) - Worlds and Frontiers of the Imaginary. Edited by Monteiro et al. London: CRC Press, 2017.

Gonçalves, C. G. and M. J. Soares. "Le Corbusier: architecture, music, mathematics: longing for classicism?” In Le Corbusier: 50 años después. Edited by J. T. Dir Cueco and Vallejo C. Coord Mejía. València: Editorial Universitat Politècnica de València, 2015.

Guest, A. H. Labanotation: The System of Analyzing and Recording Movement. New York, NY: Routledge, 1987.

Henriques, S. T. S. A influência do cinema na arquitectura europeia: dos anos 10 aos anos 30 do século $X X$ [The influence of cinema in European architecture: from the 10 s to the 30 s of the $20^{\text {th }}$ century.] Lisboa, Universidade Lusíada, 2012.

Howard, D. "Harmonic proportion and Palladio's Quattro Libri." Journal of the Society of Architectural Historians XLI, 2 (May 1982), 116-146.

Jewitt, C. "Music at the Bauhaus: 1919-1933." Tempo 213 (July 2000), 5-11.

Lino, R. Quatro palavras sobre Arquitectura e Música [Four words about Architecture and Music.] Lisboa: Valentim de Carvalho, 1947.

Lowinsky, E. E. "The concept of physical and musical space in the Renaissance." In Music in the Culture of the Renaissance and Other Essays. Chicago: The University of Chicago Press, 1989.

Mallet-Stevens, R. "O cinema e as artes: a arquitectura" [Cinema and the arts: architecture.] In Cinema e arquitectura. Edited by A. Dir. Rodrigues. Lisboa: Cinemateca Portuguesa, 1999.

Masiero, R. Estética de la Arquitectura. Madrid: Machado Libros, 2003.

Nattiez, J.-J. "Som/ruído" [Sound/noise.] In Romano, R. Dir. Enciclopedia Einaudi. Vol. 3 (Artes-Tonal/atonal). Lisboa: Imprensa Nacional - Casa da Moeda. 1984, 212-228.

Nicolescu, B. Manifesto of Transdisciplinarity. New York: State University of New York, 2002.

Nicolescu, B. Ed. Transdisciplinarity: Theory and Practice. Cresskill, NJ: Hampton Press, 2008.

Novak, M. "Breaking the Cage." In Pamphlet Architecture. Architecture as a ranslation of music. Edited by E. Martin, 1994, 69-71.

Padovan, R. Proportion: Science, Philosophy, Architecture. New York: Spon Press, 2003.

Pallasmaa, J. The Architecture of Image: Existential Space in Cinema. Helsinki: Rakennustieto, 2001.

Pérez-Gómez, A. Charles-Etienne Briseux's musical analogy and the limits of instrumentality in architecture. Nebraska: The University of Nebraska-Lincoln, 1999.

Picon, A. and Ponte, A. "Introduction." In Architecture and the Sciences: Exchanging Metaphors. New York: Princeton Architectural Press, 2003.

Soares, M. J. Para uma medida da arquitectura [For a measure of architecture.] Lisboa: Universidade Lusíada. 2004. 
Teixeira, M. Arquitectura e cinema [Architecture and cinema.] In Cinema e arquitectura. Edited by A. Dir Rodrigues. Lisboa: Cinemateca Portuguesa, 1999.

Vitruvius. The Ten Books of Architecture. Mineola, N.Y: Dover, 1960.

Wittkower, R. Architectural Principles in the Age of Humanism. London: Academy Editions, 1998. 
